\title{
The Black Sea Deep Current Velocities Estimated from the Data of Argo Profiling Floats
}

\author{
N.V. Markova, A.V. Bagaev \\ Marine Hydrophysical Institute, Russian Academy of Sciences, Sevastopol, Russia \\ e-mail: n.v.markova@mail.ru
}

\begin{abstract}
Considering scarce available data on the velocity field in the deep layers of the Black Sea, it is important to contribute by deriving the velocity vectors from indirect sources. The Lagrangian velocity vectors of the Black Sea currents on the depths below the main pycnocline are calculated using the data on the trajectories and actual profile depths of the Argo profiling drifters in 2005-2015. The values and directions of the calculated vectors in the layers $350-600,600-800,800-1200$ and $1200-1600 \mathrm{~m}$ are analyzed. The obtained results are statistically evaluated. It is shown that the prevailing number $(88 \%)$ of the modules of the calculated current velocity vectors is within the range $1-20 \mathrm{~cm} / \mathrm{s}$. The currents' velocity average for the whole period of measurements, is about $4 \mathrm{~cm} / \mathrm{s}$ in the layers $350-600$ and $600-800 \mathrm{~m}$, approximately $6 \mathrm{~cm} / \mathrm{s}$ in the $800-1200 \mathrm{~m}$ layer and $3.5 \mathrm{~cm} / \mathrm{s}$ in the $1200-1600 \mathrm{~m}$ layer. The mean current velocities from the whole data access are higher in January - March, whereas the lowest ones fall on June - October. On the background of general cyclonic circulation the meso-scale eddy structures on the specified depths are revealed. A discussion is presented on the available approaches to increase the precision and credibility of the obtained velocities magnitude and direction.
\end{abstract}

Keywords: the Black Sea, deepwater circulation, current velocity, Argo float.

DOI: 10.22449/1573-160X-2016-3-23-35

(C) 2016, N.V. Markova, A.V. Bagaev

(C) 2016, Physical Oceanography

Introduction. Investigations on the Black Sea circulation structure and physical mechanisms began to appear in the first half of the XX century [1, 2]. In recent years fundamental researches [e.g. $3-6$ ] are supplemented with a variety of the sea upper layer dynamic studying, measuring and modeling. Indeed, the most active exchange processes, motions, and the highest temperature and salinity gradients are exactly in the upper layer.

We will list the typical thermohaline and dynamic features of the Black Sea upper layers. In the vertical structure we note the upper quasi-homogeneous layer and seasonal (spring-summer) thermocline, which are mainly related to the process of wind-induced mixing and annual cycle of heat flux over the sea surface. Then we note the cold intermediate layer waters (CIL). The CIL is the layer of minimum temperatures between the seasonal and constant pycnoclines, which is bounded by $+8{ }^{\circ} \mathrm{C}$ isotherm at the depths about $50-100 \mathrm{~m}$. Main pycnocline (the level of maximum (by depth) density gradient) waters are located below the CIL at the horizons down to $\sim 300 \mathrm{~m}$. The density is mainly determined by the salinity, and the temperature remains relatively stable. Some researchers single out the transformation zone between the CIL and deep waters as a separate (intermediate) layer. Thus, they include in this layer the main pycnocline and the underlaying waters down to $1000-1200 \mathrm{~m}$ horizons [7]. In the deep layer (horizons below $1000-1200 \mathrm{~m}$ ) density value is almost constant. The processes taking place in the layer, which is deeper than $300 \mathrm{~m}$ will be called sub-pycnoclinic, and the circulation will be called a deepwater (sub-pycnoclinic) one.

The Black Sea Rim Current (BSRC) (a cyclonic one with 40 - $80 \mathrm{~km}$ width) propagates all over the basin periphery in the continental slope zone with $\sim 40-$ $50 \mathrm{~cm} / \mathrm{s}$ velocity. Two large-scale cyclonic eddies are located in the Eastern and 
Western parts of the sea (“Knipovich Glasses”). Quasistationary mesoscale (with the diameter of several tens kilometers) anticyclonic eddies are also one of the main features of the sea upper layer circulation. Eddies are named after the geographical objects which are located relatively close to them (e.g. Sevastopol, Batumi, Sinop anticyclones etc.) Outside the area of main gyres current velocities are lower and make up (according to various estimations) from 5 to $20 \mathrm{~cm} / \mathrm{s}$. The presence of short-lived submesoscale mainly anticyclonic eddies between the BSRC and the coast is noted.

Dynamic structure below the main pycnocline is still poorly studied. The Black Sea waters at these depths are saturated with hydrogen sulphide. Generally speaking, they are of little use for economic activities at the current stage, and this is the reason for the lack of new investigations. It is assumed that sub-pycnocline circulation direction is basically consistent with the circulation direction at higher horizons. Average over the depth current velocities decrease with the distance from the surface and by the $500 \mathrm{~m}$ horizon they make up about $5-10 \mathrm{~cm} / \mathrm{s}$. Prior to the publication of $[8,9]$, it was assumed that practically there were no hydrological characteristic seasonal changes in sub-pycnocline. It was also supposed that the spatial distribution of hydrological characteristic was significantly homogeneous. In $[8,9]$ it is revealed that the circulation varies over the time keeping its cyclonic orientation, and dynamic surface displays lots of eddies. In these papers average velocities are estimated to be about $5 \mathrm{~cm} / \mathrm{s}$. In [10] it is determined that bottom currents in some areas are caused by the bottom topography. Insufficient cover of field experiments data for the mentioned depths hinders more detailed investigations of deep currents physical nature. Summary data archive of expeditionary and float current measurements for the entire sea remains extremely small to date in spite of the increased number of stations performed in certain areas. Moreover, most of both archived and new data were obtained mainly at the horizons down to $300-500 \mathrm{~m}$. The results of experiments based on the modern numerical models [11 - 16] allow us to reproduce three-dimensional (by the space) structure of current field for the entire basin and all over its depth. However, the experiment results still require verification with the field data at corresponding horizons. The measurements carried out by the autonomous floating buoys can be used as one of such data sources.

The system of autonomous deep-drifting profiling floats Argo began to develop within the framework of international project on the World Ocean monitoring in 1999 [17, 18]. In the ocean the float drifts at the specified depth. Periodically it ascents to the surface to transmit the obtained data via the satellite (Fig. 1). 27 floats were deployed into the Black Sea [17] from 2005 to 2015. For the present day 9 profiling floats are in operation. Of course, there are not as much measurement data as we would like to have for the research, but even the data array collected up to date has not been fully used for the deepwater circulation assessment.

Argo floats do not measure currents directly, but they drift freely at different (parking) depths and average current velocities in deep sea layers could be calculated by the data on their movement [19]. We considered an available data archive of Argo floating drifter measurements carried out in the Black Sea over the last 10 years, from 2005 to April 2015 [20, 21], with a perspective of these data subsequent assimilation in numerical models. Successful experience of deep current data (reconstructed by the Argo profiling float trajectories) assimilation in the model already exists in the world. In [22] it is shown that profiling float drift 
caused by currents in the intermediate layer mostly follows the isobaths arrangement; average velocity values, which are about $5 \mathrm{~cm} / \mathrm{s}$, are given. Relatively active water circulation at the horizons corresponding to $500-1000 \mathrm{db}(1 \mathrm{db}$ corresponds approximately to $1 \mathrm{~m}$ depth) was also pointed out.

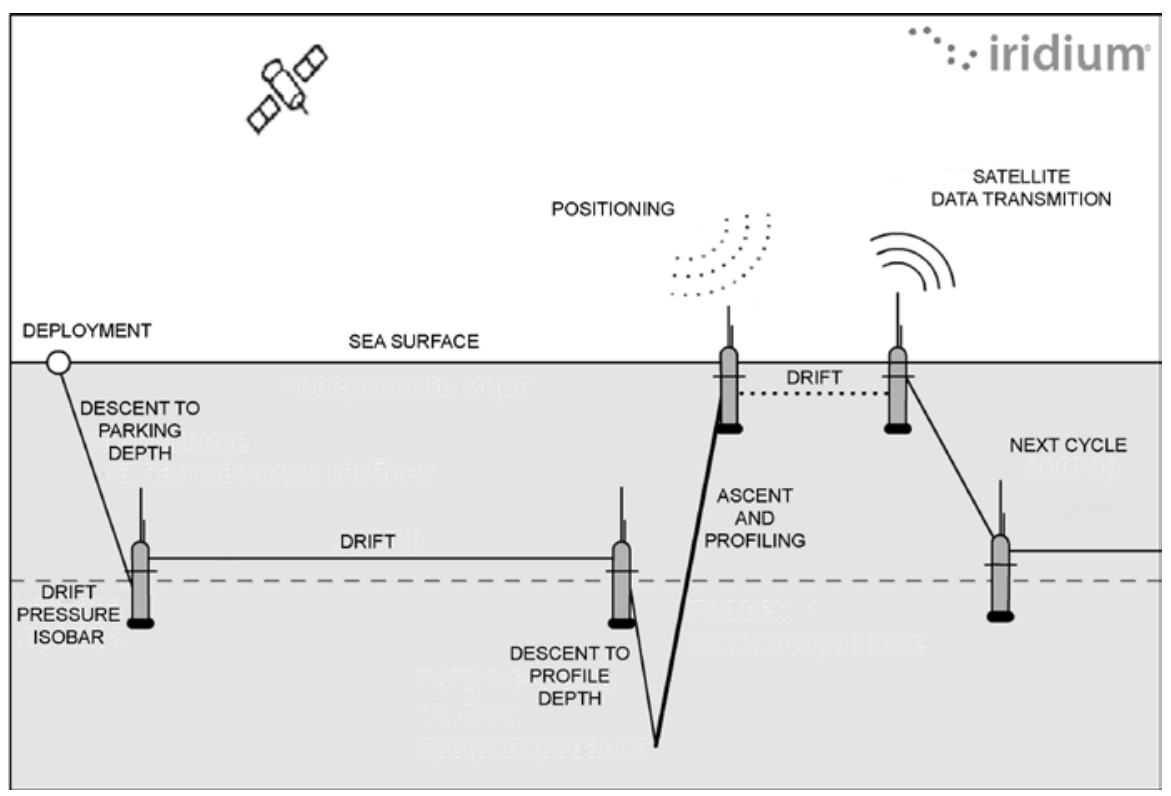

Fig. 1. An example of Argo profiling float duty cycle.

In the given paper we provide information on the calculated Lagrangian velocities of currents in the Black Sea sub-pycnocline layer at $350-1600 \mathrm{~m}$ horizons. To get it, we rely solely on the Argo drifter trajectories and maximum profiling depth data. The parking depth of $450 \mathrm{~m}$, which is the closest one (from below) to the main pycnocline deep boundary, is originally taken as the upper boundary of the layer under consideration. The layer lower boundary is due to the profiling float drift maximum depth with regard to the possible deviations. Thus, measuring data of $200 \mathrm{~m}$ parking depth drifters (which are transporting by faster currents $[1-8]$ in the main pycnocline) were not considered. The floats often drifted above their parking depth, so we could raise the upper boundary of the layer under study up to $350 \mathrm{~m}$.

Similar studies are not numerous. In addition to the abovementioned papers [8, 9], the research [23] should be noted. It is based on the analysis of seven profiling float data. These floats were in operation in $2002-2009$. In the research it was found out that mean velocities of profiling floats with $750-1550 \mathrm{~m}$ parking depths for the entire measurement period made up $2.2-2.7 \mathrm{~cm} / \mathrm{s}$, and the ones at $500 \mathrm{~m}$ parking horizon were equal to $4 \mathrm{~cm} / \mathrm{s}$. Drifter movement according their coordinates at the surface was described in details but the verification of parking depth achievement by the drifting floats was not carried out. Thus, it is not clear whether the described dynamics may be attributed to the drift horizons, or its structural elements are located in different layers vertically. This feature of Argo float duty cycle was taken into account in our work. 
Initial data and processing technique. The archives for 16 floats (which had performed the measurements in the Black Sea sub-pycnoclinic waters in 2005 early 2015 (Table 1)) were obtained from freely accessible Argo drifter databases [20, 21]. Up to the beginning of April, 2015, more than 2000 stations were performed by such floats in total. Another 11 profiling floats were drifting in the Black Sea at that time but they were not considered in the present study, as their parking depth made up only $200 \mathrm{~m}$. Downloaded data archives were additionally filtered: the information on float trajectory adequacy (i. e. on their location within the Black Sea and realistic changes of their coordinates with the time) and on the fact when the float reached the depth below $300 \mathrm{~m}$ was analyzed for each of 2057 profiles. In analogy with earlier papers [8, 23], drifter velocity at an appropriate depth was calculated as a ratio of distance covered to the time between the float surfacings. The data on each separately performed profile were used. It was important that the numbers of stations (performed by drifter) be placed in the archive without gaps. A loss of at least one (intermediate) station from the measurement chain results in averaging time increase and desired velocity vector determination accuracy decrease. This may occur primarily due to drifting float trajectory nonlinearity. The prevailing value of the period between profilings for the considered floats made up $120 \mathrm{~h}$, average surface drift duration made up about 10 h. 10 of 16 profiling floats were positioned on the surface by the Argos satellite system, and 6 floats - by Iridium (GPS) system. In [24], the errors, introduced in the velocity calculation results due to different float positioning methods, and a communication with a satellite, as well as the ways of their elimination, are discussed.

Parking horizon selection and float duty cycle programming are carried out not by its manufacturer, but by those researchers who deploy the float in the ocean, and are determined by the researcher objectives. Most often, the drifters are placed at the horizons, which are deeper than $500 \mathrm{~m}$. This is intended to make the floats forced by deep-water currents move away from the deployment area not so rapidly and to make the distance between the obtained profiles be quite short. On the contrary, in some cases it is necessary for the float to go maximum distance during its lifetime, covering with the measurements the greatest possible area of the sea. For this purpose the float is placed at a shallower depth, but this increases a risk of running ashore for it.

As a rule, a descent from parking depth to the maximum profiling one before the ascent to the surface is a part of the drifter preset program. The aim is to capture the longest possible measurement profile on the float's way to the surface. During the data analysis it was found that the depths, at which certain floats were drifted in the Black Sea, often differed from the passport parking ones (were shallower). It was determined by the maximum depths reached by the float while profiling at two next serial stations. Drift horizon, specified in the profiling float passport, was considered to be reached if maximum descent depths were greater or equal to the parking one. If the maximum depth in the profile was lesser than the parking one, the float could not reach the parking horizon for some reasons. In this case its drift below the pycnocline could also provide the information on current velocity, but at the corresponding depths. Therefore it was decided to refer the measurement data not only to the parking depths, but also to some of their 
surrounding areas (layers). If the maximum depths of previous and subsequent measurement profiles were lesser than the parking depth but both values were located in the same layer, the calculated velocity vector was assumed to be correct and was accepted for consideration for a given layer. The layers were selected with regard for the prevailing values of parking depths: $350-600 \mathrm{~m}$ (450 and $500 \mathrm{~m}$ parking depths), $600-800 \mathrm{~m}$ (750 m), $800-1200 \mathrm{~m}(1000 \mathrm{~m}), 1200-1600 \mathrm{~m}$ (1300 and $1500 \mathrm{~m}$ ).

Table 1

The amount of calculated current velocity vectors and profiles performed in the Black Sea by the Argo floats during 2005 - 2015

\begin{tabular}{c|c|c|c|c|c}
\hline $\begin{array}{c}\text { Float } \\
\text { number }\end{array}$ & $\begin{array}{c}\text { Operating period } \\
\text { under consideration }\end{array}$ & $\begin{array}{c}\text { Positioning } \\
\text { system }\end{array}$ & $\begin{array}{c}\text { Passport } \\
\text { specifications: } \\
\text { parking } \\
\text { depth/maximum } \\
\text { profiling depth, } \\
\text { db }\end{array}$ & $\begin{array}{c}\text { Total } \\
\text { number } \\
\text { of } \\
\text { conside } \\
\text { red } \\
\text { profiles } \\
\text { amount } \\
\text { of } \\
\text { calculat } \\
\text { ed } \\
\text { velocity } \\
\text { vectors } \\
\text { (in all } \\
\text { layers) }\end{array}$ \\
\hline 7900465 & $19.06 .09-20.03 .12$ & Iridium & $450 / 500$ & 134 & 131 \\
7900466 & $19.06 .09-10.12 .12$ & Iridium & $450 / 500$ & 187 & 163 \\
6901899 & $15.05 .14-23.11 .14$ & Iridium & $500 / 1000$ & 39 & 35 \\
6900803 & $01.04 .11-14.07 .13$ & Argos & $750 / 1500$ & 142 & 68 \\
6900804 & $01.04 .11-14.07 .13$ & Argos & $750 / 1500$ & 166 & 81 \\
6900805 & $31.03 .11-21.03 .15$ & Argos & $750 / 1500$ & 286 & 155 \\
6901895 & $15.08 .13-16.03 .15$ & Argos & $750 / 750$ & 117 & 114 \\
7900590 & $11.09 .13-22.03 .15$ & Argos & $750 / 2000$ & 113 & 69 \\
7900593 & $12.07 .17-28.04 .15$ & Iridium & $750 / 2000$ & 60 & 56 \\
7900591 & $29.12 .13-29.04 .15$ & Iridium & $1000 / 1000$ & 88 & 84 \\
7900592 & $28.12 .13-28.10 .14$ & Iridium & $1000 / 1000$ & 82 & 55 \\
5902291 & $30.04 .10-16.06 .10$ & Argos & $1300 / 1300$ & 24 & 6 \\
4900489 & $27.03 .05-17.08 .08$ & Argos & $1500 / 1550$ & 155 & 121 \\
4900540 & $27.03 .05-15.10 .08$ & Argos & $1500 / 1550$ & 173 & 161 \\
4900541 & $14.08 .06-14.03 .09$ & Argos & $1500 / 1550$ & 124 & 122 \\
4900542 & $07.08 .06-05.01 .10$ & Argos & $1500 / 1550$ & 161 & 137 \\
\hline
\end{tabular}

The results. Four current velocity vector arrays, corresponding to each of the selected layers, were obtained. In total there turned out to be 1558 constructed vectors, the rest $25 \%$ of initial data did not meet the criteria specified above. If we perform the averaging procedure over all calculated vectors, with $95 \%$ degree of probability average current velocities will make up: $3.0 \pm 0.3 \mathrm{~cm} / \mathrm{s}-$ in $350-$ $600 \mathrm{~m}$ layer, $3.7 \pm 0.2 \mathrm{~cm} / \mathrm{s}$ - in $600-800 \mathrm{~m}$ layer, $5.1 \pm 0.6 \mathrm{~cm} / \mathrm{s}-$ in $800-$ $1200 \mathrm{~m}$ layer and $3.2 \pm 0.2 \mathrm{~cm} / \mathrm{s}$ - in 1200 - $1600 \mathrm{~m}$ layer. However, the constructed arrays contained velocity vectors with small (lesser than $1 \mathrm{~cm} / \mathrm{s}$ ) 
modules comparable with the error of their computation. To increase the estimation accuracy it was decided to exclude such vectors from the consideration and to recalculate mean current values. The number of such small vectors made up 193 ( $12 \%$ of all constructed vectors). The median of their modules is $0.8 \mathrm{~cm} / \mathrm{s}$, they are directed variously and are mostly concentrated in the western part of the sea. Small velocity values could be obtained, for example, when the float got into an eddy structure. In this case, the coordinates for the period between the surfacings changed insufficiently. The nature of such vectors needs additional analysis and investigation. So, further we will consider $88 \%$ of all calculated vectors and $66 \%$ of all profiles measured by floats.

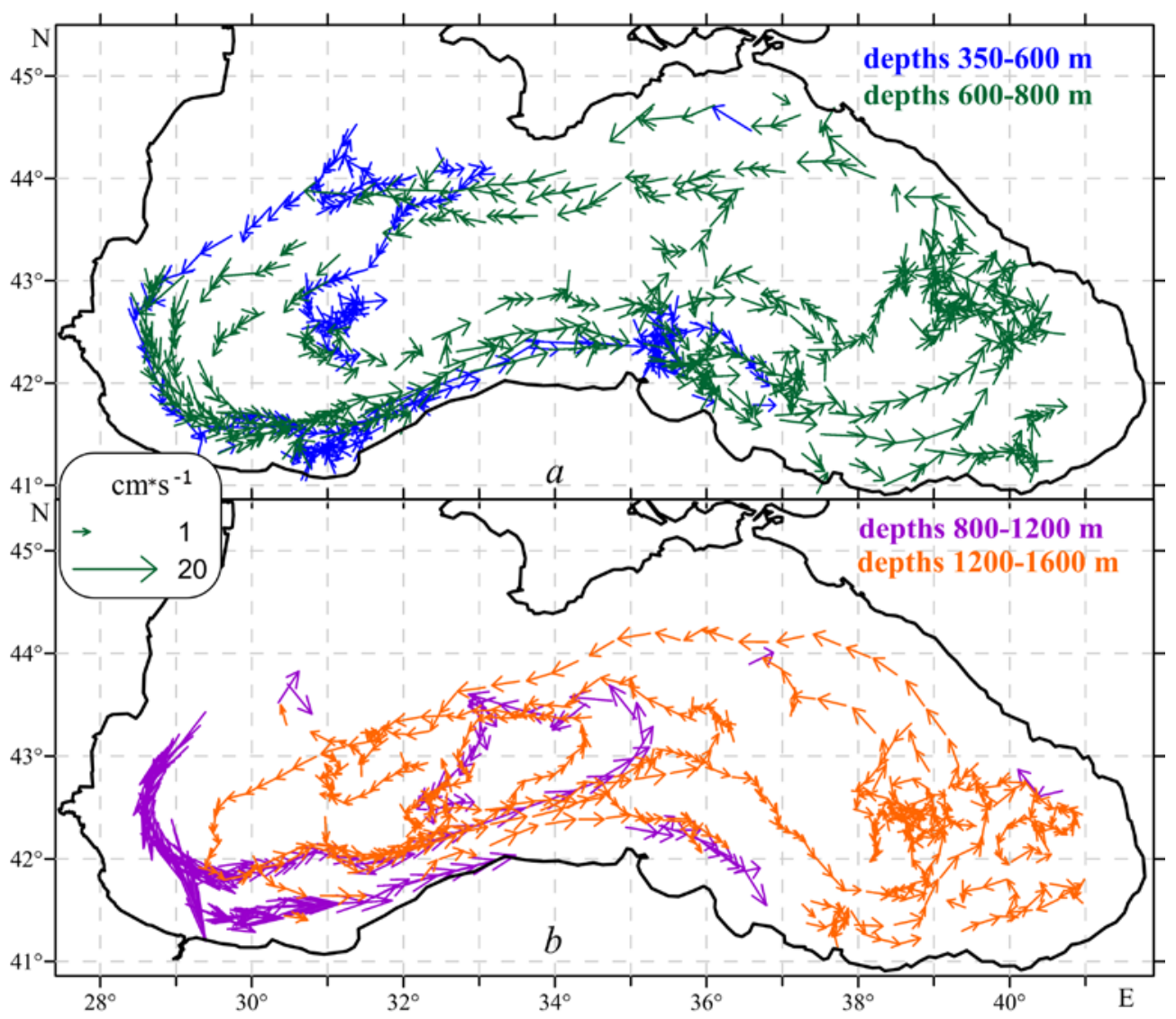

Fig. 2. Current velocity vectors: $a$-in 350 - 800 m layer (450, 500, 750 m parking depths); $b$-in 800 - 1600 m layer (1000, 1300, 1500 m parking depths)

In Fig. 2 velocity vector maps for $350-800$ m (Fig. 2, a) and $800-1600 \mathrm{~m}$ (Fig. 2, $b$ ) layers are represented. The greatest number of reconstructed vectors falls on Western and South-western parts of the sea. General circulation is dominated by cyclonic direction. In the Nothern part of the sea currents are mainly directed to the West, and in the Southern one - to the East. It was traced that the floats got into separated eddies. Moreover, in the central and western parts of the sea they mostly got into synoptic-scale eddies, and in the south-eastern part - into mesoscale ones. 
The mean velocity in $350-600 \mathrm{~m}$ and $600-800 \mathrm{~m}$ layers is approximately the same and it makes $\sim 4 \mathrm{~cm} / \mathrm{s}$; in $800-1200 \mathrm{~m}$ layer it makes approximately $6 \mathrm{~cm} / \mathrm{s}$, in 1200 - $1600 \mathrm{~m}$ layer - approximately $3.5 \mathrm{~cm} / \mathrm{s}$ (Tabl. 2). Annual variation of mean velocity vector modules is represented in Fig. 3 . It is determined that mean current velocities in January - March are $10-20 \%$ higher, and the lowest values are observed in June - October.

Table 2

\section{The number of obtained current velocity vectors and the mean velocity for the layers}

\begin{tabular}{c|c|c|c}
\hline Layers, $\mathrm{m}$ & $\begin{array}{c}\text { The number of } \\
\text { vectors }\end{array}$ & $\begin{array}{c}\text { Mean } \\
\text { velocity, cm/s }\end{array}$ & $\begin{array}{c}95 \% \text { confidence } \\
\text { interval, cm/s }\end{array}$ \\
\hline $350-600$ & 269 & 3.6 & \pm 0.4 \\
$600-800$ & 496 & 4.0 & \pm 0.2 \\
$800-1200$ & 132 & 5.7 & \pm 0.6 \\
$1200-1600$ & 474 & 3.5 & \pm 0.2 \\
\hline
\end{tabular}

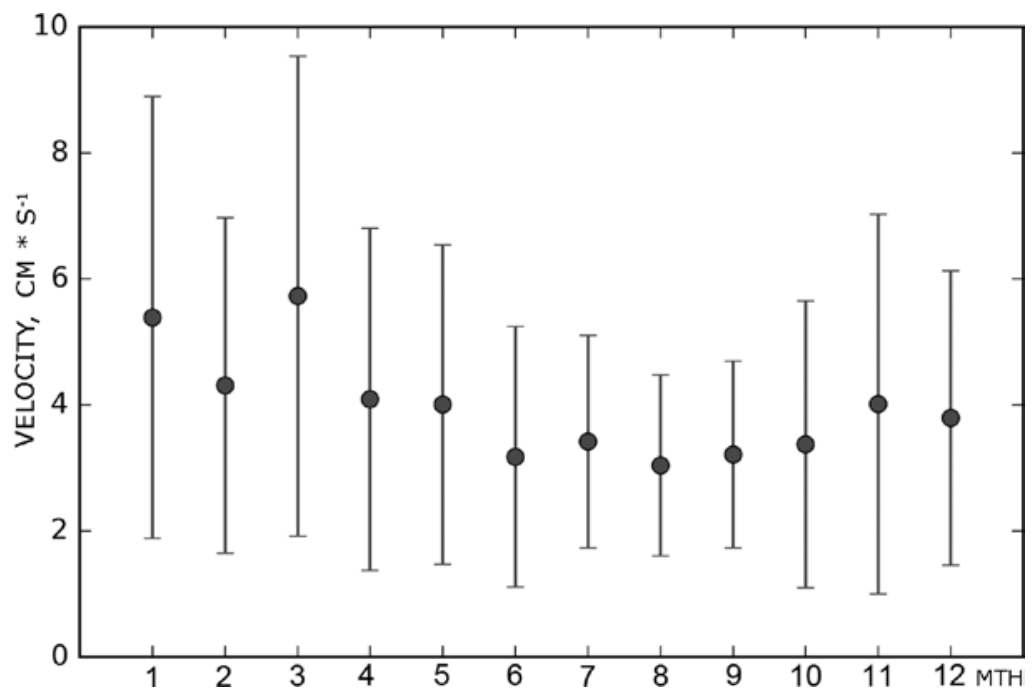

Fig. 3. Monthly mean values (marked by dots) of all constructed current velocity vectors (vertical segments show root-mean-square deviation)

For the further current direction analysis, all vector coordinates were divided by $43^{\circ} \mathrm{N}$ and so belonged to "northern" or "southern" sea areas. 8 diagrams of velocity vector direction distribution by the layers separately for each area were drawn. They demonstrated the stability of the transport direction from West to East in the "southern" part of the sea and from East to West - in the "northern" one. In [25] it is shown that if the obtained velocities are higher than $3 \mathrm{~cm} / \mathrm{s}$, deepwater current directions are stable. Furthermore, they usually coincide with the isobaths directions and do not need to be corrected. On the contrary, when the velocities are 
lower than $3 \mathrm{~cm} / \mathrm{s}$, current directions are sufficiently unstable and they should be additionally corrected. The most frequently occurring current velocity vector directions vary within $3-4$ rhumbs $\left(30-40^{\circ}\right)$. The most frequent velocity amplitude makes up $4-8 \mathrm{~cm} / \mathrm{s}$, increasing up to $16 \mathrm{~cm} / \mathrm{s}$ only at $1000 \mathrm{~m}$ horizon. It might be related to the fact that $1000 \mathrm{~m}$ horizon measurement coverage was the poorest (see Tabl. 2). Moreover, most of these measurements were performed in winter (from January to March). The histograms of data distribution by months showed that the rest of the considered layers were covered with measurements throughout the year more evenly.

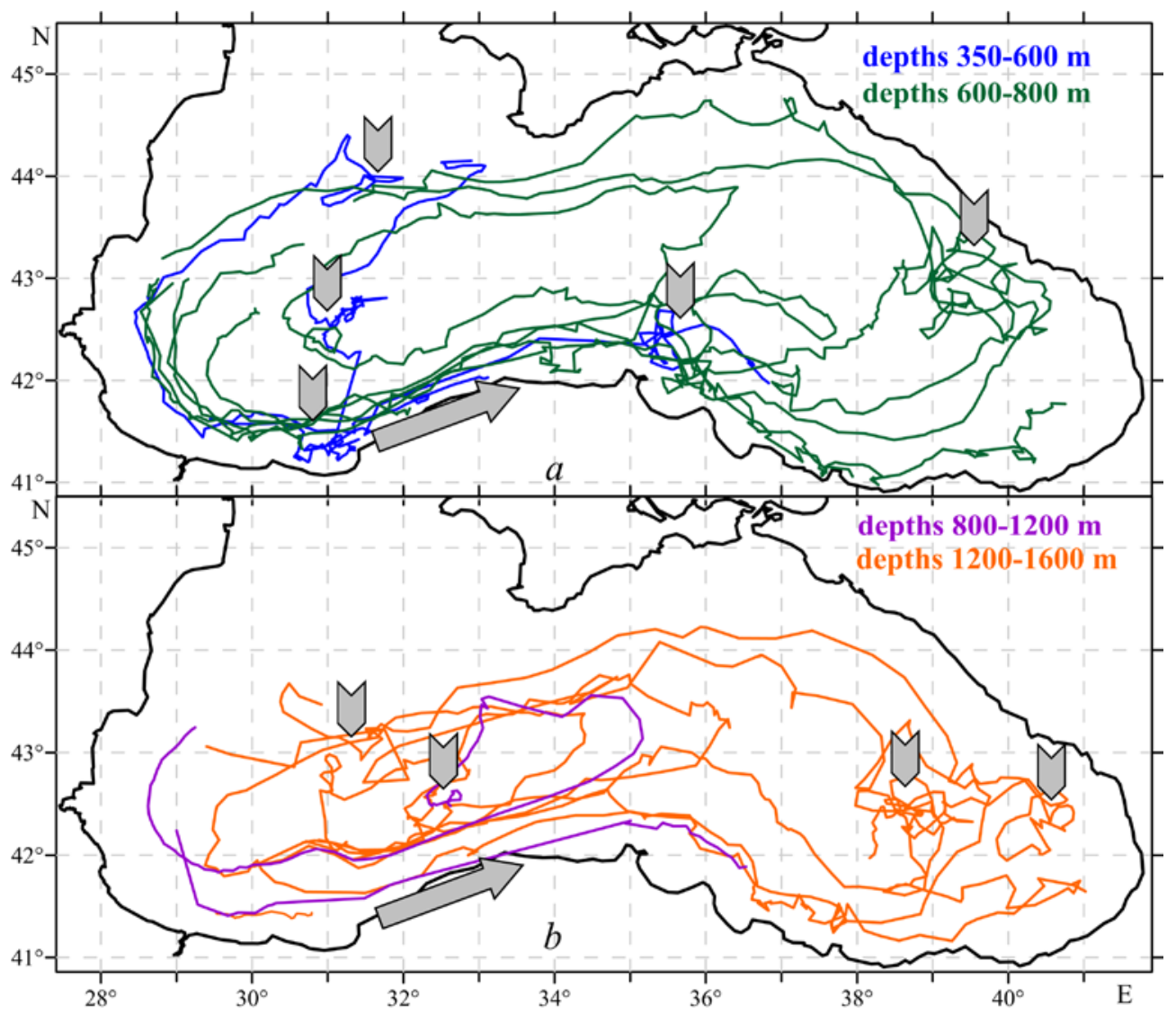

Fig. 4. Float trajectories: $a$-in 350 - 800 m layer, 450, 500, $750 \mathrm{~m}$ parking depths; $b$ - in $800-1600$ $\mathrm{m}$ layer, 1000, 1300, $1500 \mathrm{~m}$ parking depths (the area of steady deep-sea currents is marked by arrows, mesoscale eddies are denoted by markers)

For comparison with the earlier works [8, 23], in the same way the float trajectory maps (Fig. 4) based on the profile station coordinates were constructed. The obtained trajectories are to some extent the projections of three-dimensional underwater drift onto the sea surface and so may indicate the areas with circulation features (e. g. the areas with steady stable currents and eddy formation zones). Drifter movement direction corresponds to vector field, represented in Fig. 2. When comparing Fig. 4 (float trajectory) and Fig. 2 (vector velocities) not only the 
individual dynamic features can be noted, but it also can be assessed at which horizons they are located. For instance, in the eastern part of the Anatolian coast profiling float trajectories are rather winding (Fig. 4, $a, b$ ) and it may indicate that the floats get into the chain of coastal eddies and/or pass the bottom orographic features. In that zone none of velocity vectors were defined at any of the corresponding horizons (Fig. $2 a, b$ ) (and were not considered in averaging) according to our technique. In accordance with our algorithm, this may take place for two reasons. Either the floats sharply changed their depth between the stations (this is why their data were taken into account in none of the layers), or, more likely, drifters moved at higher horizons in this area (therefore their velocities were eliminated from the calculations for sub-pycnocline). In previous studies these velocities were attributed to computational horizons and therefore introduced an error into the given assessment.

In Fig. $4 a, b$ such deepwater circulation features can be identified. Cyclonic current flows along the continental slope at the basin periphery. Western cyclonic gyre zone is clearly defined. The area of steady deepwater currents in the western part of the Anatolian continental slope (to the East from the Bosphorus) is marked by the arrows in the figure. All the floats, which got into this current, had the correlated trajectories and velocity vectors. Perturbation in density field in this area is introduced only by Sakarya River inflow. This leads to mesoscale eddy formation near its estuary at $350-600$ m horizons. Mesoscale eddies (denoted by markers in the figure) are also located near Kizilirmak River estuary (in 350 $800 \mathrm{~m}$ layer) in the eastern part of the Anatolian coast. The eddies, corresponding to Sevastopol anticyclone, mesoscale cyclone in the center of the western part of the basin and Batumi anticyclone in the south-western part of the sea, are found in all considered layers. Apparently, Batumi anticyclone vertical axis can be tilted and its structure may contain several eddy structures. The mentioned features are also noted in the vector velocity field (Fig. 2).

Discussion. From the methodological point of view, our work for the Black Sea may be appropriately compared only with the studies in $[8,23]$, where the velocity calculations (as well as in the given work) are of evaluative character. That's due to a great number of error sources were not taken into consideration. We will list such sources below and will show some possible ways of the result correction for the case when direct data on float underwater drift period are absent.

Determination of precise coordinates for the float with no GPS-sensor. Most of the profiling floats from our 10 years sample had no sensors for GPSpositioning. Their coordinates were determined via the Argos system satellite. In some works it is specified that up to $10 \%$ of total amount of stations performed by the float may have errors in coordinates [26]. For the time needed for coordinate determination the float may be shifted by surface currents. In this case, numerical reanalysis results together with Lagrangian transport model are used for the maximum likelihood trajectory determination both at the surface and underwater. When sufficient statistical material on drifter (equipped with GPS-sensors) trajectory is accumulated, the significance of results, previously obtained from the floats via Argos satellite system, will decrease. The data on profiling float GPSpositioning at the surface (i.e. on the time and precise coordinates of its descent and 
surfacing) will also allow us to clarify the distance covered by the float only underwater.

The vertical shift of the velocity during the float ascent may be significant and may make up to $20 \%$ of the calculated velocity value (taking into account a large difference between current velocities at the sea surface and at the parking horizon). Its influence on the result could even be decisive in case of weak deepwater counter current. However, most of instrumental measurement data do not confirm the presence of stable anticyclonic circulation at depths greater than $300 \mathrm{~m} \mathrm{[7].}$

The information on the distance covered by the drifter at the depth may be corrected (with regard to profiling depth and average ascent velocity equal to $\sim 10 \mathrm{~cm} / \mathrm{s}$ ), if necessary, for each profile using numerical simulation results and/or according to climatic current data in the certain sea area.

Windage and Stokes drift may also make a certain contribution to float transport at the surface during its communication with the satellite. Little is known about Argo float windage, but this factor can be neglected when just a small antenna is above the surface.

Stokes drift strongly depends on the season and geographical coordinates. The analysis of synoptic and wind-induced wave maps in the float location point is the easiest way to correct drifter coordinates in such a case.

Drifter inertia when the direction and velocity of the surrounding current changed. Although during the free drift the float has neutral buoyancy and may be considered as a passive tracer, it also has an inertial mass of $20-35 \mathrm{~kg}$. When a sufficiently dramatic change in ambient current (for example, at mesoscale turbulence) takes place, drifter does not change its impulse instantly, it takes some period of time. Perhaps it is an inertial "departure" from the trajectory that explains several float go off the circular orbit in mesoscale anticyclonic eddies.

Despite the possible calculation errors, the Argo float deepwater measurement data array for such a long period is considered for the first time in our work to find deep current velocities in the Black Sea. These data were insufficient to separate the measurements by the seasons and to study the within-year variability. However, it was possible to assemble them according to layers (which included the main parking horizons) and to demonstrate a certain average velocity and transport direction in the sub-pycnocline layer. We traced the trajectories of several drifters on the sea surface (by the satellite detected coordinates) and described drifters motion at the depth in the first approximation. The amount of profiles performed up to the present date does not provide a decisive and complete picture of deepwater circulation. However, the constructed trajectories allow us to speak of general cyclonic transport direction and presence of eddy structures of different signs.

Conclusion. We obtained the following results from the initial data array for the profiling float trajectories and maximum profiling depth, taking into account the introduced assumptions.

1. Lagrangian velocity vectors were calculated and Lagrangian current velocity maps were constructed in four layers corresponding to the values of Argo profiling float parking horizons. Mean current velocities at the horizons under the main pycnocline made up $\sim 4 \mathrm{~cm} / \mathrm{s}$. They increased up to $6 \mathrm{~cm} / \mathrm{s}$ in the $800-$ 
$1200 \mathrm{~m}$ layer. The highest current mean velocities for the entire sample were observed in January - March, and the lowest ones - in June - October. In general, drifter movement direction corresponded to cyclonic type of basin circulation.

2. A number of synoptic (with a diameter of $\sim 100-105 \mathrm{~km}$ ) and mesoscale (with a diameter of $\sim 50 \mathrm{~km}$ ) eddies (in which the floats in the considered layers were involved) of different signs were traced on the maps of current velocity trajectories and vectors. Some of such eddies may be associated with the known features of surface circulation (the Batumi anticyclone, Eastern and Western cyclonic gyres, Kizilirmak eddy, etc.) or with the bottom topography features. In contrast to the works $[8,9,23]$, we obtained the statistical information not only on velocity vector magnitudes, but also on their directions. It was revealed that the highest current stability was found out above the continental slope. In the deepwater part and the areas with complicated orography, eddy structures are most common.

3. Approximately $88 \%$ of the magnitudes of the calculated current velocity vectors are within $1-20 \mathrm{~cm} / \mathrm{s}$ range. The magnitudes of the rest of the vectors were under $1 \mathrm{~cm} / \mathrm{s}$. Such velocities are likely to reflect the float motion in submesoscale eddies, loops and other similar cyclic structures with a period approximately equal to the float underwater drift one (prevailing value is about 5 days) and with a radius of about Rossby deformation radius $(15-20 \mathrm{~km}$ for the Black Sea). The obtained maximum velocity magnitudes $(\sim 20 \mathrm{~cm} / \mathrm{s})$ are higher than obtained in the previous works and in model assessments we knew. This somewhat changes the idea of the intensity of the Black Sea sub-pycnocline layer circulation.

Acknowledgements. The authors are grateful to I.P. Chubarenko, S.P. Lyubartseva and V.N. Belokopytov for participation in the discussion of the work results and for valuable comments on the article structure.

The work was carried out with the financial support of Russian Foundation for Basic Research within the framework scientific project NO.16-05-00264 A.

\section{REFERENCES}

1. Knipovich, N.M., 1932, "Gidrologicheskie issledovaniya v Chernom more [Hydrological studies in the Black Sea]”, Tr. Azovo-Chernomorskoy nauchno-promyslovoy ekspeditsii, VNII mor. rybnogo khoz-va, iss. 10, 272 p. (in Russian).

2. Caspers, H., 1957, "Black Sea and Sea of Azov", Treatise on Marine Ecology and Paleoecology, Geolog. Soc. Amer. Memories, vol. 67, no. 1, pp. 803-890.

3. Filippov, D.M., 1968, "Tsirkulyatsiya i struktura vod Chernogo morya [The Black Sea waters structure and circulation]”, Moscow, Nauka, 319 p. (in Russian).

4. Blatov, A.S., Bulgakov, N.P. \& Ivanov, V.A. [et al.], 1984, "Izmenchivost' gidrofizicheskikh poley Chernogo morya [Variability of the Black Sea hydrophysical fields]”, Leningrad, Gidrometeoizdat, 238 p. (in Russian).

5. Marchuk, G.I., Kordzadze, A.A. \& Skiba, Yu.N., 1975, "Raschet osnovnykh gidrologicheskikh poley Chernogo morya na osnove metoda rasshchepleniya [Calculation of major hydrological fields of the Black Sea on the basis of the splitting method], Izvestiya USSR, Atmos. Ocean. Phys., vol. 11, no. 4, pp. 379-393 (in Russian). 
6. Kordzadze, A.A., 1989, "Matematicheskoe modelirovanie dinamiki morskikh techeniy (teoriya, algoritmy, chislennye eksperimenty) [Mathematical modeling of the sea current dynamics (theory, algorithms, numerical experiments)]”, Moscow, OVM AN SSSR, 218 p. (in Russian).

7. Ivanov, V.A., Belokopytov, V.N., 2011, “Okeanografiya Chernogo morya [The Black Sea oceanography]”, Sevastopol, MGI NAN Ukrainy, 212 p. (in Russian).

8. Korotaev, G., Oguz, T. \& Riser, S., 2006, "Intermediate and deep currents of the Black Sea obtained from autonomous profiling floats”, Deep-Sea Res. II: Topical Studies in Oceanography, vol. 53, no. 17-19, pp. 1901-1910.

9. Oguz, T., Latun, V.S. \& Latif, M.A. [et al.], 1993, "Circulation in the surface and intermediate layers of the Black Sea”, Deep-Sea Res., vol. 40, no. 8, pp. 1597-1612.

10. Dobrovol'skiy, A.D., Zalogin, B.S., 1982, “Morya SSSR [The seas of the USSR]”, Moscow, Izd-vo MGU, 192 p. (in Russian).

11. Stanev, E.V., 1989, "Numerical modelling of the circulation and the hydrogen sulphide and oxygen distribution in the Black Sea”, Deep-Sea Res., vol. 36, no. 7, pp. 1053-1065.

12. Kubryakov, A.I., 2014, "Modelirovanie tsirkulyatsii i protsessov massoperenosa $v$ Chernom more $v$ prilozhenii $k$ zadacham operativnoy okeanografii [Modelling of circulation and mass transfer processes in the Black Sea as applied to operational oceanography]”, Doctor's thesis, Sevastopol, MGI NAN Ukrainy, 399 p. (in Russian).

13. Demyshev, S.G., Korotaev, G.K., 1992, "Chislennaya energosbalansirovannaya model' baroklinnykh techeniy okeana na setke $C$ [Numerical energy-balanced model of the ocean baroclinic currents at the $C$ grid]", Chislennye modeli i rezul'taty kalibrovochnykh raschetov techeniy $v$ Atlanticheskom okeane, Moscow, IVM RAN, pp. 163-231 (in Russian).

14. Zalesny, V.B., Diansky, N.A. \& Fomin, V.V. [et al.], 2010, "Numerical model of the circulation of the Black Sea and the Sea of Azov”, Russ. J. Numer. Anal. Math. Modelling, vol. 25, no. 6, pp. 581-609.

15. Mizyuk, A.I., Senderov, M.V. \& Korotaev, G.K. [et al.], 2016, “Osobennosti gorizontal'noy izmenchivosti temperatury poverkhnosti $v$ zapadnoy chasti Chernogo morya po rezul'tatam modelirovaniya s vysokim prostranstvennym razresheniem [Features of the surface temperature horizontal variability in the Black Sea western part according to the results of modeling with high spatial resolution]”, Izvestiya Atmos. Ocean. Phys., vol. 52, no. 5, pp. 1121 (in Russian).

16. Ibraev, R.A., Ushakov, K.V. \& Khabeev, R.N., 2012, "Vikhrerazreshayushchaya 1/10 model' Mirovogo okeana [Eddy-resolving $1 / 10^{\circ}$ model of the World Ocean]", Izvestiya Atmos. Ocean. Phys., vol. 48, no. 1, pp. 45-55 (in Russian).

17. Riser, S.C., Freeland, H.J. \& Roemmich, D. [et al.], 2016, "Fifteen years of ocean observations with the global ARGO array”, Nat. Clim. Change, vol. 6, no. 2, pp. 145-153.

18. Grayek, S., Stanev, E.V., 2012, “Assessment of the Black Sea observing system. A focus on 2005 - 2012 ARGO campaigns”, Ocean Dyn., iss. 12, pp. 1665-1684 (in Russian).

19. Rosell-Fieschi, M., 2014, “Ocean Velocities as Inferred from ARGO Floats: Methodology and Applications”, PhD Thesis, Institut de Ciències del Mar, CSIC, 121 p.

20. ARGO Data Management, http://www.ARGOdatamgt.org/ (Access date: 29.05.2015)

21. Global Ocean Data Assimilation Experiment, USGODAE, ARGO Page, http://www.usgodae.org/ARGO/ARGO.html (Access date: 23.06.2015).

22. Nilsson, J.A.U., Dobricic, S. \& Pinardi, N., [et al.], 2012, "Variational assimilation of Lagrangian trajectories in the Mediterranean ocean Forecasting System”, Ocean Sci., pp. 249259, doi:10.5194/os-8-249-2012. 
23. Gerasimova, S.V., Lemeshko, E.E., 2011, “Otsenka skorostey glubokovodnykh techeniy po dannym ARGO [Assessment of deep current velocities according to ARGO data]”, Sistemy kontrolya okruzhayushchey sredy, iss. 15, pp. 187-196 (in Russian).

24. Lebedev, K.V., Yoshinari, H. \& Maximenko, N.A. [et al.], 2007, “YoMaHa'07: Velocity data assessed from trajectories of $A R G O$ floats at parking level and at the sea surface”, Hacker IPRC Technical Note, no. 4 (2), 16 p.

25. Park, J.J., Kim, K., 2013, "Deep currents obtained from $A R G O$ float trajectories in the Japan/East Sea”, Deep-Sea Res. II: Topical Studies in Oceanography, pp. 169-181, doi:10.1016/j.dsr2.2012.07.032.

26. Kobayashi, T., Nakamura, T. \& Ogita, N. [et al.], 2009, "Quality control of Argo surface trajectory data considering position errors fixed by Argos system”, Proc. of the OceanObs'09: Sustained Ocean Observations and Information for Society Conference (Annex), ESA Publication WPP-306, doi:10.5270/OceanObs09. 